\section{BA Institute of \\ YK Business Administration \\ 六下 \\ Karachi \\ Leadership and Ideas for Tomorrow}

Business Review

Volume 2 Issue 1 January - June 2007

$1-1-2007$

\title{
Authentic leadership style and its implications in project management
}

\author{
Shamas-ur-Rehman Toor \\ National University of Singapore, Singapore \\ George Ofori \\ National University of Singapore, Singapore \\ Faisal Manzoor Arain \\ Institute of Business Administration, Karachi, Pakistan
}

Follow this and additional works at: https://ir.iba.edu.pk/businessreview

Part of the Business Administration, Management, and Operations Commons, and the Business Intelligence Commons

\section{(c) (1)}

This work is licensed under a Creative Commons Attribution 4.0 International License.

\section{Recommended Citation}

Toor, S., Ofori, G., \& Arain, F. M. (2007). Authentic leadership style and its implications in project management. Business Review, 2(1), 31-55. Retrieved from https://doi.org/10.54784/1990-6587.1112

This article is brought to you by iRepository for open access under the Creative Commons Attribution 4.0 License and is available at https://ir.iba.edu.pk/businessreview/vol2/iss1/5. For more information, please contact irepository@iba.edu.pk. 


\title{
ARTICLE
}

\section{Authentic Leadership Style and its Implications in Project Management}

\author{
Shamas-ur-Rehman Toor \\ National University of Singapore, Singapore \\ George Ofori \\ National University of Singapore, Singapore
}

Faisal Manzoor Arain

Institute of Business Administration, Karachi, Pakistan

\begin{abstract}
Project leader/manager is vital for project management organization. Project manager should be able to influence the followers positively, manage several activities together, communicate with various stakeholders at the same time, manage conflicts, take difficult and risky decisions, deal with several socio-economic and cultural challenges, handle several deadlines, control the resources, solve disputes, and finally achieve the project objectives. To accomplish these jobs, the project leader must develop an appropriate leadership style which can be employed under such circumstances for effective performance outcomes. Moreover, leadership researchers have argued that current frameworks do not suffice the need to develop future leaders who can face the challenging future with valor. This situation necessitates the need for a new form of leadership. This paper presents a case for changing and more demanding role of project leader for managing the exigent future projects. The authors argue that a new breed and generation of project leaders is required to fight the turbulent business environment. This new leadership can be provided by developing authentic leadership style in project leaders. It is argued that authentic leadership style is unique and best suited to project management practices. The paper also discusses benefits and applications of authentic leadership style in project management. Proposals are made for authentic leadership development in project leaders. The study would be beneficial for management professionals in the business industry in general.
\end{abstract}

Keywords: Leadership, Management, Project Leader, Organization.

\section{INTRODUCTION}

T $\mathrm{n}$ the traditional organization - the organization of the last one hundred years - the skeleton or internal structure, was a combination of rank and power. In the emerging organization, it has to be mutual understanding and responsibility.

With much emphasis on project management systems, construction firms are now seeking professionals with better management and leadership skills rather than technical skills (Dulaimi, 2005; Arain, 2005). This finding is not limited to construction industry alone. All project-based organizations are looking for personnel who have better 
leadership skills to cope with multitude of issues faced on modern project management organizations. Research in project management has also fully recognized the importance of leadership in project-based organizations (Keegan and Hartog, 2004) and effective performance of the project manager is recognized as the single most critical factor affecting successful project outcomes (Powl and Skitmore, 2005). Research has also shown that there is significant relationship between the project leader's professional qualification, his leadership style, team composition (Odusami et al., 2003); and the competencies of project managers as evidenced in terms of key behaviors (Dainty et al., 2006).

However, Turner and Muller (2005) have noted that the literature on project success factors does not typically mention the project manager and his or her leadership style or competence as a success factor on projects. This is in direct contrast to the general management literature, which views effective leadership as a critical success factor in the management of organizations (Turner and Muller, 2005). There has been a debate that the corresponding need for leadership skills development has not been adequately researched (Skipper and Bell, 2006; Toor and Ogunlana, 2006). Evidence in this regard is the observation of Cleland (1995). He mentions the limited description of 'leadership' in the Project Management Body of Knowledge (PMBOK) and notes the subject as "terra incognita", the unknown territory. The situation has remained the same after a decade and PMBOK still provides very little discussion on leadership (Toor and Ofori, 2006c).

Despite the scarcity of leadership research in project management, the authors notice that emerging literature in the domain is consistently emphasizing the need for effective leadership in project managers who have been widely acknowledged as one of the important success factors (Odusami, 2002; Long et al., 2004; Toor and Ogunlana, 2005; Toor and Ofori, 2006c). Also, leadership (or the lack of it) has been identified as a key variable for the functioning of teams and one of the main reasons for the success or failure with which team-based work systems are implemented (Katzenbach, 1994). Though people define leadership differently (Bogus and Rounds, 2006), researchers in the field of project management mostly rely on a functional or operational definition of project leadership rather than relying on a broader and vague conceptualization. That is why there has been confusion if project managers are different from project leaders. To overcome this misunderstanding, researchers elaborate that the person in charge of a project may carry one of a variety of titles (e.g. project leader or project manager) and he/she is usually the main focal point of responsibility for the project (Cooke-Davies, 1990; Harrison, 1992).

McCuen (1999) asserts that leadership consists of the knowledge and skills that the individual possesses and employs to persuade others to enthusiastically work toward the completion of the plan of action that the leader has established." According to Goffee and Jones (2000), effective leadership requires "being yourself, with skill". Thamhain (2004) takes a distinct stand and argues that effective team leaders are social architects who recognize the interaction of organizational and behavioral variables and can cultivate a climate of active participation, accountability and result- orientation. 
Leadership in organizations requires sophisticated skills in leadership, administration, organization, and technical expertise (Toor and Ogunlana, 2006).

A number of research studies suggest various taxonomies of leadership styles for effective project management. Nonetheless, there is no evidence about universality of certain leadership styles which can be used under all sets of situations and circumstances in different cultures and countries. Another issue regarding the contemporary taxonomies of leadership styles is that most of them are self-centered, task-centered, relationshipcentered, or change-centered (Toor and Ofori, 2006c). These styles do not tell if the effort behind the leadership is genuine, authentic, reliable, and truthful. Also, these styles can be pretended like "chameleon" and hence are prone to be used for certain personal purposes. Briefly, leadership style is a big dilemma which business professionals face today. In this paper, the authors make an attempt to answer the intricate question of "what leadership best suits to project professionals under all conditions". It is argued that the answer lies in developing a natural leadership style which is based on personal values, convictions, aspirations, and motivations. This leadership style is a best possible match of heart and mind with actions of leader. Leadership researchers refer to such leaders as authentic leaders. In the next sections, the authors present a case for changing role of project manager due to abundant business challenges and dilemmas. Discussion has been made on various popular taxonomies of leadership styles to argue that these taxonomies do not fulfill the demands of future leadership. In the end, the authors argue that "authentic leadership" and "authentic leaders" are solution to the so-called leadership crisis of today's business world.

\section{CHALLENGES IN THE MODERN BUSINESS ENTERPRISES}

Describing the challenges of modern business enterprises, George (2003) argues that capitalism has become the victim of it own success. According to his view, measures of business development such as growth, cash flow, and return on investment are fading away and new criterion of success is "meeting the expectations of security analysts". To reach the earning targets, investments are cut back resulting in the growth potential of company. To achieve the targets of profit maximization and to satisfy shareholders, CEOs go to extreme measures. They have become forgetful of human and social capitals which earn long-term success for the companies. They are anxious about profit maximization at the expense of their employees and organizational values. Businesses of today are undoubtedly going through a tumultuous era and markets are more challenging than ever before.

Swift changes in the business environment, organizational structures, technology, and lifestyles are introducing a considerable rethinking of leadership development (Bowman and Farr, 2004; Arain et al., 2004). Modern businesses face bigger challenges due to rapidly changing world. These challenges comprise socio-cultural, economic, technological, legal and regulatory, environmental, and ethical (Toor and Ofori, 2006d). There are certain industry specific challenges which are pertinent to particular industries but mainly comprise: globalization, rapidly growing markets, growing size of the projects, integration of processes, fast track nature of the projects, multi-project 
environment, concept of franchising, larger private sector participation in infrastructure projects, increasing vertical integration in the packaging of construction projects, proliferating trends of strategic alliances such as joint ventures, consortiums, mergers, acquisitions, and partnering relationships. These rapid changes have led to the widespread adoption of flattened organizational structures and empowerment strategies. To improve the organization's operational flexibility, several modern types of organizations have also evolved like: networks, collaborations, federalist structure, shamrock structure, and virtual organizations (Bolman and Deal, 1997).

Among the outside environment challenges, socio-cultural challenges include: spreading wave of terrorism, wars, political upheavals, security problems, increased private participation in the infrastructure projects, and cross cultural issues. Economic challenges include funding difficulties, uncertain economic conditions, threats of high inflation due to increased energy prices, fluctuating stock markets, exchange rates, and cash flow problems. Technological challenges include: increased use of information and communication technology (ICT) resources, e-procurement, large technological differences between developed and developing countries, matters of technology transfer, and technological innovation and advancement. Legal and regulatory challenges include: different legal systems, litigation procedures, and arbitration methods within and across the countries. Environmental and sustainability challenges include: strict environmental regulations, increased awareness and need for sustainable development, and deconstruction of the built infrastructure. Ethical challenges include: prevailing corruption in the developing countries, fraudulent, unethical, and unprofessional practices in professions.

\section{CHANGING ROLE OF PROJECT MANAGERS}

Under the effect of vast array of challenges discussed in the preceding section, role of project managers is constantly changing in the organizations. Quality of management largely determines the success of projects completed either in the country of an organization of beyond its borders. Especially with fast pace of globalization and internationalization of projects has resulted in demands and expectations of clients. Quality standards are more stringent and firms are facing huge competition in terms of winning the projects both inside their home country and abroad. Also, increased demand for foreign direct investment (FDI) has forced the governments to relax the regulations for foreign companies. Race of attracting more FDI has widened the boundaries of businesses and local companies are facing bigger challenges to survive in their homelands. Therefore, they are going cross borders to find opportunities which suit their specialties and expertise. Researchers have argued that projects which are carried out beyond national borders create special problems for managers, such as dealing with multiethnic work teams, operating within local laws, regulations, social customs, and importing materials (Enshassi and Burgess, 1990).

Under such circumstances, project leaders are expected to have better comprehension of socio-economic, cultural, and political setup of the countries they are deployed in. 
They must also understand the religious and ethnic sensitivities of their team members to create harmony in the teams. Also, it is additionally beneficial if they are conversant with history of socio-cultural development of the country. In today's world, it is hard to imagine a homogenous project team in terms of ethnicity, nationality, religion, and culture. Therefore, project managers must have a broader knowledge of various customs, cultures, countries, religions, and ethnicities to deal with several team members. Any insensitive actions can not only destroy the trust but can also result in ill effects on the project performance.

In addition, project managers now operate with a significant degree of power and autonomy in return for increased responsibility for the operational performance of their projects (Dainty et al., 2006). They handle huge budgets and manage large volumes of all sorts of resources. They deal with several stakeholders of the project and satisfy everyone's distinct demands. They now deal with public and have to answer critical questions regarding their projects. They are liable for everything happening on their projects and are accountable for the outcomes. They resolve disputes among various parties involved in the project and they take critical decisions which have long-term impact on project health. To fulfill a number of roles including those of facilitator, coordinator, motivator and politician (Briner et al., 1996), project managers' demanding and multifaceted job necessitates the development of more sophisticated approaches to managing their development and performance in a way which supports both specific project objectives and the wider business goals of the organization (Dainty et al., 2006).

\section{DIFFERENTIATING LEADERSHIP FROM MANAGEMENT}

In several instances, people use the terms "manager" and "leader" in the same context. Therefore, a clear difference should be recognized between leadership and management and more specifically leaders and managers. Mowson (2001) believes that leaders may not excel at management and, what is more often the case, managers do not necessarily make great leaders. Kotter (1990) explains that management is about planning, budgeting, organization, staffing, controlling, and problem-solving. Management mainly comprises planning, scheduling, budgeting, organizing, and executing. It ensures that every project task starts and finishes in time and under allocated resources. In short, management is more task-oriented and objective. On the similar lines, managers are concerned with achievement of certain organizational objectives. They make the best use of available resources to accomplish the job efficiently and effectively. Their focus is on short-term gains and their work surrounds the day-to-day goals.

Leadership, as Kotter (1990) argues, is more about establishing direction, aligning people, and motivating and inspiring others. Leadership is concerned with long-term outcomes and future goals of the organizations. Leadership is more about people and less about tasks. Leaders often put many of the same skills and interests to good use but often to better effect because they focus on areas such as discovering solutions (not problems), managing changing conditions, excelling in spite of organizational structure, and inspiring personnel to achieve their goals. 
Leaders achieve objectives through energized and excited subordinates who share their passion, vision, and direction. Good leaders feel comfortable challenging the status quo and finding efficient—as well as long-term—solutions to challenges. Good leaders develop through a never-ending process of self-analysis, and the utilization of education, training, and experience to improve. The best leaders are continually working and studying to improve their leadership skills (Gharehbaghi and Mcmanus, 2003).

Now that the difference between leaders and managers is clear, a simple question that arises is if we need leaders or managers to run the project organizations. Looking at the challenges the managers face today and their increasing role and responsibility in project organizations, it is obvious that only management can not bring the fruits. As Skipper and Bell (2006) propose that there is progressively more a need for engineers in project management positions to also have people oriented skills, i.e. leadership skills, to complement their technical skills. Gil et al. (2005), present a different perspective. They view that both leaders and managers employ a mix of leadership and management behaviors appears much closer to reality so that they must combine the necessary skills to direct day-to-day affairs effectively (a role traditionally associated with management) while at the same time anticipating and managing change (leadership main role). Yukl (2002) argues that rather than seeking to establish distinctions between managers and leaders, the two can be explained jointly using the same processes and models.

This leads to a simple understanding that managers of contemporary and future organization can not just rely on their management and technical skills which are usually referred to as hard skills. They will have to be more conversant with soft or leadership skills. To be successful in the modern business world, managers will have to find a balance between their management and leadership abilities so that they can not only fulfill the performance criteria but also can create a harmony within their team so build successful and futuristic organizations. This debate does not at all aims to prove that managers are not better than leaders or that only leadership qualities are the ultimate solution to modern business challenges. The authors argue that management alone is not an answer. Managers should tie the management with leadership so that they can enjoy the benefits of both worlds.

\section{LEADERSHIP STYLE}

Over the last several decades of leadership research, a number of leadership styles have been proposed for organizational leaders such as: transactional, transformational, laissez faire, charismatic, democratic, autocratic, consultative, joint decision making, authoritative, participative, servant, tyrant, task oriented, relationship oriented, production-oriented, employee-oriented, performance or maintenance, directing, coaching, supporting, delegating, authority-compliance, impoverished management, country club management, team management, middle of the road management and so on (Toor and Ofori, 2006c). Yang and Shao (1996) hypothesize a positive relationship between team effectiveness and the balance of the eight supervisory roles which are: 
facilitator, mentor, innovator, broker, producer, director, coordinator, and monitor. Findings indicate that managers in the organizations should not only be concerned about the development and balance of the eight roles, but should also change role emphasis during the different stages in the team development (Yang and Shao, 1996). In the following, some research studies are quoted which have been conducted to analyze the most suitable leadership style for certain projects.

\section{Task vs. People oriented style}

Plethora of research on task vs. people oriented leadership styles has produced mixed results. Makilouko (2003), in his study of multicultural projects, found three multicultural project leadership styles. Considerable majority of project leaders they studied indicated a solely task oriented leadership style. The same leaders also indicated cultural blindness, ethnocentrism, parochialism, or in-group favoritism. The seven leaders that indicated almost solely relationships- orientation, or both task and relationships-orientation, indicated also cultural sympathy and three leadership strategies to maintain team cohesion and to avoid cross-cultural problems. In another research study, Lee-Kelley and Loong (2003) attempt to explore if the project leader's orientation is related to his situational perception of project control. Their survey has found only partial support for the proposed relationships. In an in-depth empirical analyses of the relationship between IS leadership behavior and BPR outcomes for 30 BPR projects, Sutcliffe (1999) found that found that successful BPR leaders use leadership styles that fit the type of task that needs to be done and the needs of the people that will perform the tasks. Researchers of this investigation also note that successful BPR leaders balance their efforts between meeting the needs of the people doing the work and the needs of the work.

Among one of the earliest studies, Monaghan (1981) observed that the project managers, who were high in task and low in people consideration, produced an acceptable level of commercial performance. Another research described the project managers as "socially independent" though the calculated LPC scores suggested the task-oriented behavior of the subjects (Dulaimi and Langford, 1999). Seymour and Elhaleem (1991) also noted the effectiveness of project managers fairly synonymous with task-oriented leadership. Rowlinson et al. (1993) examined variations of leadership style employed by the same construction managers in different circumstances. They found that project leaders tended to use a supportive style in feasibility study and pre-contract stages of works and a directive style as construction progressed. Dulaimi and Langford (1999) also documented the project managers in their study as socially independent. They noted that the project manager's personal orientation and the situational variables varied independent of one another. Their results show that the personal orientation of the project managers has no influence on their behavior.

In another study of construction site managers (CSMs), Fraser (2000) found that the high scoring CSMs on the effectiveness scale favored team-style leadership; those CSMs following a production style of leadership scored the lowest of all; and CSMs using a compromise leadership style had middle range effectiveness scores. Contrary 
to earlier studies, Ogunlana et al. (2002) found that the relationship-oriented leadership style was considered to be more important than the task-oriented style for project managers in Bangkok. Fellows (2003) in a study of the quantity surveyors in Hong Kong observed that quantity surveyors were mostly relationship orientated and tended to adopt the supportive style of leadership. They noticed that the expressed preference for relationship orientation was stronger amongst contractors than consultants.

These case studies illustrate that there is no accurate answer if task-oriented leaders are more effective or people-oriented. The reasons are clear: there is no one best leadership style which can be claimed as all time best (Fiedler, 1967; Vroom and Jago, 1988); context is important when it comes to measuring management knowledge (Chanlat, 1996; Arain and Low, 2005) and leadership style (Fellows et al., 2003) and its effectiveness. Moreover, contingency theories of leadership also advocate the fact that leadership style can not be separated from the prevailing conditions under which leadership is being exercised (Fiedler, 1967; House, 1971; Hersey and Blanchard, 1982). Several other researchers also agree to the fact that leadership style should vary according to the situation and the leader must find a fit between his style, those who are being lead, and situational factors and demands (Gilbert, 1983; Muir and Langford, 1994; Kangis and Lee-Kelley, 2000). These studies do mention that the leadership style should suit the situation but fail to suggest how a leader should shift from one style to another.

\section{Transformational vs. Transactional style}

Transformational vs. transactional leadership style has also been studied by a number of researchers in project management field though there is a dearth of both theoretical and empirical research in project-based organizations (Keegan and Hartog, 2004). Thite (2000) conducted an empirical research aimed at identifying successful leadership styles for managers of Information Technology/Systems projects. Their results indicated that a combination of transformational and technical leadership behaviors augment the effectiveness of transactional leadership leading to high project success. Researchers of this study also acknowledge that there is no one leadership style that is effective in all project situations and hence recommend an underlying yet flexible style characterized by organizational catalyst, intellectual stimulation, behavioral charisma, and contingent reward behaviors for enhanced leadership effectiveness.

Keegan and Hartog (2004) report the findings of an empirical study comparing the relationship between transformational leadership style and employee motivation, commitment and stress for employees reporting to either project or line managers. Their results indicate that although project managers are not perceived as less transformational, the relationships between transformational leadership and outcomes is weaker for employees who report to project managers than for those who report to line managers.

In their study of construction project managers, Chan and Chan (2005) observe that all five of the transformational factors and three of the transactional factors are 
significantly correlated with leadership outcomes of leader effectiveness, extra effort by employees, and employees' satisfaction. In another study of construction project managers in Turkey, Giritli and Oraz (2004) observed that: (i) female and male managers were similar in terms of their transactional leadership behavior but their transformational practice was significantly different which suggested the task-oriented style of both sexes in a gender-congruent context; (ii) managers in higher positions were stronger in pacesetting style than those in lower management positions which indicated that senior managers led by example, yet exerted tight control over poor performance of their subordinates. In a recent study of construction project managers in Thai construction industry, Toor and Ogunlana (2006) observed that the attributes of transformational leaders were rated high as compared to those of transactional leaders for successful performance on large construction projects. They also noted that use of authority and punishment was rated among the lowest rated leadership behaviors.

These case studies clearly demonstrate that transformation leadership style (based on idealized influence, inspirational motivation, and intellectual stimulation, and individualized consideration) has been proven to be more effective as compared to transactional leadership style (which is based on contingent reward, management by exception (active and passive). A number of researchers have argued that transactional skills are important for effective management; however, in today's world, organizations are continuously changing and hence expect the leaders to employ a different approach to lead the change (Daft, 2003). Since it has been argued that business world is constantly changing due to globalization and several other factors, transactional leadership is not a solution.

Moreover, there has been criticism on transformational and transactional leadership. Yukl (1999) presents a strong case in this regard and makes several points to illustrate conceptual weaknesses in transformational and transactional leadership. He believes that the underlying influence processes for transformational and transactional leadership are still unclear. He further argues that each transformational behavior includes diverse components, which makes the definition more ambiguous. The partially overlapping content and the high inter-correlation found among the transformational behaviors raise doubts about their construct validity. Moreover, some important transformational behaviors (such as inspiring, developing and empowering) are missing in the Bass (1996) version of the theory and in the MLQ, which was designed to test the theory (Bass \& Avolio, 1990). The transformational leadership also fails to identify any situation where it can prove to be detrimental. Extending his critique on transactional leadership, Yukl argues that transactional leadership includes a diverse collection of (mostly ineffective) leader behaviors that lack any clear common denominator. The authors argue that transformational and transactional leaderships lack another important conceptual weakness that is their "fit" with the situation. It is understandable that transformational and transactional leadership styles are not universal may not well match with certain situations. 


\section{Charismatic Style}

Wang et al. (2005), in a study of three-hundred companies listed in the "Top 500 of The Largest Corporations in Taiwan 2001", that have implemented ERP (enterprise resource planning) systems, suggest that leaders should demonstrate more charismatic behaviors to establish the ERP project team members cohesiveness and, thus, improve team performance. Cheung et al. (2001) empirical survey conducted in Hong Kong indicated that the charismatic leadership style of design team leader has the most impact on team member satisfaction. More interestingly, same authors note that the charismatic leadership style is often the most dominant style in Asian countries (Cheung et al., 2001) and is often positively related to the effectiveness of the leader. These findings are similar to those presented by presenters of charismatic leadership theory. For example, charismatic leaders have been shown to receive higher performance evaluations (Bass, 1985) and have been rated by superiors as top performers (Hater and Bass, 1988; Wang et al., 2005).

There has been widespread confusion about the meaning of charismatic leadership (Yukl, 1999), partly due to how different theorists define it (Bryman, 1993). Therefore, more clear and consistent definition of charismatic is required to alleviate this confusion. Moreover, creators of charismatic theories also disagree about the relative importance of the underlying influence processes and behaviors in charismatic leadership (Yukl, 1999). He further points towards an important issue that charismatic leadership seems advocate socially acceptable behaviors that increase follower perception of leader expertise and dependence on the leader. However, there can be manipulative behaviors with which leaders exploit their position and authority. These manipulative behaviors are known as negative side of charisma as suggested by Conger and Kanungo (1987) who believe that there are two sides of charisma, positive and negative. Charismatic leadership depends on leader's passion, confidence, and exceptional ability to persuade and sway people. Such leaders enjoy enormous magnitude of position, expert and personal power; and are highly vulnerable to narcissism which may lead to self-serving and self-centered behaviors. Narcissism makes such leaders forgetful of the organizational needs and they start pursuing their personal goals. Overwhelming desire for power and importance lead them to ignore the followers, view point of others, realities and facts, open feedback, need of leadership development in followers, and requirement of coaching and mentoring the subordinates for future (Wart, 2005; Conger, 1989).

\section{LEADERSHIP STYLE DILEMMA}

There are many who are living far below their possibilities because they are continually handing over their individualities to others. Do you want to be a power in the world? Then be yourself. Be true to the highest within your soul and then allow yourself to be governed by no customs or conventionalities or arbitrary man-made rules that are not founded on principle.

Naum (2001) states that large capital investment projects coupled with high complexity of decision issues can require different styles of leadership. He acknowledges that 'a 
participative style of leadership with bureaucratic organization is expected to be more appropriate than a directive style'. In contrast, Nicholas (1990) suggests that a less participating, more directive style might be more appropriate when there is less time and high pressure to complete the work. Dulewicz and Higgs (2005) observe that relationship between the approach of leaders (or their leadership style) and the context in which they operate is seen to be important. These contexts can be different set of circumstances such as: cultural environment, project requirements, team members, availability of resources, and organizational support. Though some research studies show the universality of leadership styles (such as supportive, continent reward, and charismatic), most other styles (such as directive, participative, and contingent punishment) are culturally specific (Dorfman et al., 1997).

Gilbert (1983) argues that no one style of project management is constantly effective, and the manager must continually adapt his approach to match current circumstances. Muir and Langford (1994) also share similar perspective and note in their research findings that the desirable management style is contingent on the task to be undertaken and subordinate's expectations in relation to the task and their relationship with the manager. Considering the life cycle of projects, Odusami and Ameh (2006) argue that different leadership styles are expected to be exhibited in different phases of the project life cycle. During the different phases of the design process, style may need to allow for more debates, fine-tuning and deliberations. Yet, during the construction phases, they may be more structured and dominant. During a concrete pour under adverse conditions for example, they may need to be tough, direct and even dictatorial. In settling disputes, they may need to be creative and conciliatory (Hopper, 1990).

Discussion in the earlier section portrays that different leadership theories suggest different leadership style. Moreover, there is no evidence about universality of certain leadership style which can be used under all sets of situations and circumstances. Contingency leadership theories suggest that leader should adapt to the situation and assume a matching leadership style. For example, Naum (2001) argues that leaders may have to change their leadership from time to time or combine elements of different styles until the right balance between concerns for tasks and concern for people is obtained. However, this doctrine is not only complex but practically difficult to adopt in real life scenarios. Projects are multifaceted and complex jobs where a number of stakeholders are involved. Moreover, in large and multi-project environment, one project manager is responsible for a number of projects which may be at different level of completion and may have varying degree of complexity and other factors. Level of authority and power vested in the project manager may also vary from project to project. In fast track project, where dynamics move faster as compared to ordinary and usual projects, it is expected that project conditions change fast.

Under such complex circumstances, is it really possible for a project manager to alter his leadership style so quickly? Accepting this means that a project manager may have to be task-oriented in the morning, people-oriented in the afternoon, participative in the evening, and delegative on the next morning. At the same time, he has to be democratic within certain project teams and autocratic within the others. Sometimes, 
he performs the role of transactional leader and the other times try to exhibit the behaviors of transformational or charismatic leader. In short, he has to become a realtime "chameleon leader" who changes his color ever hour and every day. He must wear different faces in front of different people to get approval of leadership. Contingency theories fail to suggest how a leader will successfully change from one leadership style to another without creating a negative or inconsistent image. Also, the authors argue that every project manager may not have the capability to act in such ways.

This view point is shared by Conger (2004) who argues that "we have been losing an appreciation for the fact that leadership approaches do indeed depend upon the situation". He further believes that one of the most intriguing issues in leadership studies is whether managers and executives can develop a leadership capacity with a great versatility in style or approach. Simply put, can managers vary their leadership styles significantly given changing circumstances? Or is leadership style such a product of personality and inbuilt personal behaviors that variations in style are limited to incremental changes? (Conger, 2004).

Another issue regarding the contemporary taxonomies of leadership styles is that most of them are self-centered, task-centered, relationship-centered, or change-centered (Toor and Ofori, 2006c). These styles do not tell if the effort behind the leadership is genuine, authentic, reliable, and truthful. Also, these styles can be pretended like "chameleon" for certain personal purposes. Though Conger (2004) opines that the "chameleon leadership capability" is important for leaders to adapt new situations easily, the current authors tend to think differently. An important point which the authors want to emphasize is authenticity of leadership. If leaders change their behavior and style too frequently to adapt to new situations and fit with new circumstances, would that act be considered as genuine? If leaders develop the capability of "chameleon leadership", how can we guarantee that they are acting in the best interest of their colleagues and organizations even by demonstration of altruistic behaviors? These behaviors can be simply a pretence rather than reality and there is likelihood that leaders use this "chameleon leadership capability" for their personal purposes. Sensing the situation, several leadership researchers have argued that current frameworks are not sufficient for developing leaders of future (Luthans and Avolio, 2003; Avolio, et al., 2004; Avolio, Luthans, and Walumbwa, 2004; Gardner, Avolio, et al., 2005).

These arguments illustrate that leadership style is a big dilemma which business professionals face today. With several leadership styles discussed in the literature, business leaders are at lost to what leadership style suits them the best and can bring them the success in their position. Very often, leadership training programs focus on developing a particular leadership style in the trainees without understanding what sort of organizations they work for and more than that, without any comprehension of their personal motives, convictions, aspirations, self-knowledge, and self-awareness. This leads to a big confusion as the trainees can not find sufficient congruence between their inner-self and the leadership style which is being advocated for successful performance. As a result, they get puzzled and loose both sides of the picture. They can neither get hold of their own leadership style nor do they benefit from leadership 
training program. That is why Gardner et al. (2005) ask the leadership training consultants if they have any evidence that they developed even a single leader.

\section{A SOLUTION TO DILEMMA}

The answer to the intricate questions mentioned in the earlier sections lies somewhere in a natural leadership style which is based on personal values, convictions, aspirations, and motivations. This natural leadership style is a best fit of leader's personality, behaviors, and actions. If an individual is able to reach this "best fit mode", there would be no need to act like a "chameleon leader" to change the leadership style from one situation to another. Leadership researchers have called this new type of leadership which is based on self awareness and self regulation as authentic leadership and such leaders are known as authentic leaders. George (2003), in his best selling book, argues that to become an authentic leader, every one of us has to have our own leadership style which is consistent with our own personality and character. This is because if we confirm to a style that is not consistent with who we are, we can never become authentic leaders. Adhering to a normative style due to organizational demands can never help achieving the goal of authentic leadership development. Having this unique style, one has to hone his/her style to be effective in different environments to lead different types of people. This does not mean that leaders have to change their style under different situation. They have to develop the capability of working with different people under varying situations. Simply put, they must hone their leadership quotients such as: social, emotional, spiritual, ethical, decision, communication, flexibility, and innovation quotient (Toor and Ofori, 2006a).

The important feature the leader needs to develop in this regard as an intrinsic personality trait is "authenticity" which means "to thine own self be true" in Greek philosophy. Terry (1993) believes that to be authentic is to act, to embody, to engage, and to participate in life. The term authenticity as used here refers to "owning one's personal experiences, be they thoughts, emotions, needs, wants, preferences, or beliefs, processes captured by the injunction to know oneself and further implies that one acts in accord with the true self, expressing oneself in ways that are consistent with inner thoughts and feelings (Harter, 2002). This authenticity of character helps developing the individuals as authentic leaders.

Avolio et al. (2004) define authentic leaders as "those who are deeply aware of how they think and behave and are perceived by others as being aware of their own and others' values/moral perspectives, knowledge, and strengths; aware of the context in which they operate; and who are confident, hopeful, optimistic, resilient, and of high moral character" (Gardner et al., 2004). Shamir and Eilam (2005) believe that authentic leaders have following characteristics: "(1) rather than faking their leadership, authentic leaders are true to themselves (rather than conforming to the expectations of others); (2) authentic leaders are motivated by personal convictions, rather than to attain status, honors, or other personal benefits; (3) authentic leaders are originals, not copies; that is, they lead from their own personal point of view; and (4) the actions of authentic leaders are based on their personal values and convictions." 
Presenting their perception of authentic leaders, Shamir and Eilam (2005) believe that: authentic leaders are originals, not copies; they do not fake their leadership; they do not take on a leadership role or engage in leadership activities for status, honor or other personal rewards; their actions are based on their values and convictions; what they say is consistent with what they believe, and their actions are consistent with both their talk and their beliefs. Authentic leaders exhibit a higher moral capacity to judge dilemmas from different angles and are able to take into consideration different stakeholder needs (May et al., 2003). Such leaders are not necessarily transformational, visionary, or charismatic leaders. But they are the leaders take a stand that changes the course of history for others, be they organizations, departments or just other individuals (May et al., 2003). Other researchers posit that authentic leaders, "by expressing their true self in daily life live a good life (in an Aristotelian way), and this process results in self-realization (eudaemonic well-being) on the part of the leaders, and in positive effects on followers' eudaemonic well-being" (Ilies et al., 2005).

George (2003) believes that leadership is authenticity, not a style. He describes the authentic leaders as individuals who genuinely desire to serve others through their leadership. They take a pleasure in empowering others rather than concentrating power around them. They are guided by qualities of heart and mind together. They are consistent and self-disciplined individuals and never compromise on their principles. In describing the authentic leaders further, George (2003) maintains that the best leaders are autonomous and independent. They are not overly complaint and responsive to unjustified demands of situation and therefore take decisions which are based on principles rather than self-interests. Advocating the benefits of authentic leadership, Avolio and Gardner (2005) argue that "authentic leadership can make a fundamental difference in organizations by helping people find meaning and connection at work through greater self-awareness; by restoring and building optimism, confidence and hope; by promoting transparent relationships and decision making that builds trust and commitment among followers; and by fostering inclusive structures and positive ethical climates."

\section{HOW AUTHENTIC LEADERSHIP IS DIFFERENT}

Cooper et al. (2005) emphasize on discriminant validity of authentic leadership construct to ascertain whether the construct is redundant with other similar constructs. Due to being a new construct, difference between authentic leadership and other forms of leadership is makes an important research question. Creators of authentic leadership construct conceptualize it as a "root construct" underlying all positive approaches to leadership (May et al., 2003; Avolio et al., 2004; Gardner et al., 2005). It has been argued earlier that authentic leadership can contain other forms of positive leaderships such as transformational, charismatic, or servant. However, in contrast to transformational leadership in particular, authentic leadership may or may not be charismatic (George, 2003).

Distinguishing between authentic and charismatic leaders, proponents of authentic leadership construct expect that authentic leaders will influence follower self-awareness 
of values/moral perspective, more based on their individual character, personal example, and dedication, than on inspirational appeals, dramatic presentations, or other forms of impression management (Gardner and Avolio, 1998; Avolio and Gardner, 2005). Also, authentic leadership theory includes an in-depth focus on leader and follower self-awareness/regulation, positive psychological capital, and the moderating role of a positive organizational climate (Adler and Kown, 2002). This feature is not a prime consideration in other leadership theories.

Avolio and Gardner (2005) argue that to be viewed as transformational by both the definitions of Bass' (1985) and Burns' (1978) necessitate that a leader be authentic; importantly, however, being an authentic leader does not necessarily mean that the leader is transformational. For example, authentic leaders may or may not be actively or proactively focused on developing followers into leaders, even though they have a positive impact on them via role modeling (Avolio and Gardner, 2005). They further argue that the key distinction between authentic and transformational leaders is that authentic leaders have their own deep sense of self and they know where they stand on important issues, values and beliefs. Distinguishing between authentic and charismatic leaders, Avolio and Gardner (2005) note that charismatic leaders employ rhetoric to persuade, influence, and mobilize followers, an authentic leader energizes followers by creating meaning and positively socially constructing reality for themselves and followers.

While differentiating between authentic and other forms of leadership, it is essential to note that authentic leadership is "a process that draws from both positive psychological capacities and a highly developed organizational context, which results in both greater self-awareness and self-regulated positive behaviors on the part of leaders and associates, fostering positive self-development" (Luthans and Avolio, 2003). Authentic leadership goes beyond transformational and charismatic leadership as leaders can be highly authentic but not charismatic at all (Luthans and Avolio, 2003).

\section{AUTHENTIC LEADERSHIP DEVELOPMENT}

"Have the courage to say no. Have the courage to face the truth. Do the right thing because it is right. These are the magic keys to living your life with integrity."

--W. Clement Stone

"Wisdom is not a product of schooling but of the life-long attempt to acquire it." --Albert Einstein

A unique and authentic leadership style is not something which can be developed overnight, through a seminar or workshop, reading books on leadership, watching videos of leaders, joining toastmasters club, taking a leadership course in business school, winning an executive post in the organization, imitating the role models, or memorizing some inspirational clichéd and jargon. It takes several years of personal development, experience, and plain hard work (George, 2003). Developing as an authentic leader is a life-span program as several leadership researchers (Luthans and 
Avolio, 2003; Avolio, 2005; Avolio and Luthans, 2006) and practitioners (George, 2003) have proposed. The most important factors which would matter is this "lifespan" program is constant ambition for learning and improvement through selfawareness (values, identity, goals and motivations, convictions, and emotions), selfregulation (balanced processing, authentic behavior, relational processing), selfverification, and self-actualization.

According to Luthans and Avolio (2003), authentic leadership development is a dynamic lifespan process and various trigger events during different stages of life help shaping this development over time. These experiences in life lead to development of positive psychological capacities (confidence, hope, optimism and resiliency). Under the influence of positive organizational context, the trigger events and life challenges result in positive self-development which provides self-awareness and self-regulation behaviors. The positive self development eventually results in development of authentic leadership in individuals.

In their antecedent model of authentic leadership development, Toor and Ofori (2006b) argue that the life of a leader comprises various episodes in which significant individuals play their roles in different capacities. These episodes can have both positive and negative influences on the personality of a leader, or leader-self. Outcomes of these episodes eventually profile the actual leader-self. The leader-self characterizes the self-concept, self-knowledge, identity personal values and norms, personality dimensions, nature of social relationships, motives, leadership style, and various other features which are attributed to leaders and leadership. Leadership antecedents can be both positive and negative; however, their impact is significant and can bring major variations in the behaviors of the effected persons. Moreover, this impact can be both short lived and long lived depending on the nature of the significant experiences. Toor and Ofori (2006b) propose that a positive mediation of these antecedents results in development of authentic leadership behavior and style of individuals.

Gardner et al. (2005) present a self-based multi-level model of authentic leader and follower development. The theoretical foundations for their model are provided by the literature on the self and identity. They believe that the developmental processes of leader and follower self-awareness (values, identity, emotions, goals and motives) and self-regulation (balanced processing, authentic behavior, and relational transparency) are vital for authentic leader and follower development. According to this model the influence of the leader's and followers' personal histories and trigger events are considered as antecedents of authentic leadership and follower-ship, as well as the reciprocal effects with an inclusive, ethical, caring and strength-based organizational climate. The proponents of this model view positive modeling as a primary means whereby leaders develop authentic followers. Posited outcomes of authentic leader-follower relationships include heightened levels of follower trust in the leader, engagement, workplace well-being and veritable, sustainable performance.

Ilies et al. (2005) also present their multi-component model of authentic leadership. To explore the specific links between authentic leadership and both leaders' and 
followers' eudemonic well-being, Ilies et al. (2005) develop their model starting from the nascent multi-component conceptualization of authenticity. They propose a fourcomponent model of authentic leadership that includes self-awareness, unbiased processing, authentic behavior/acting and authentic relational orientation. Proponents of this model argue that, from a developmental perspective, these dimensions can be roughly mapped onto the six aspects of human wellness proposed by Ryff and Keyes (1995) to reflect human actualization (self-acceptance, environmental mastery, purpose in life, positive relationships, personal growth, and self-determination). Namely, selfawareness and unbiased processing should lead to increased self-acceptance and environmental mastery, and also help one define one's purpose in life; authentic relational orientation should lead to positive relationships; self-awareness and unbiased processing should enhance one's personal growth through self-development; and authentic behaviors and actions are by definition self-determined (Ilies et al., 2005).

According to Shamir and Eilam (2005), authentic leader development has four components: development of a leader identity as a central component of the person's self-concept; development of self-knowledge and self-concept clarity, including clarity about values and convictions; development of goals that are concordant with the selfconcept; increasing self-expressive behavior, namely consistency between leader behaviors and the leader's self-concept. They further present a life story approach to leadership development which comprises four themes: leadership development as a natural process; leadership development out of struggle; leadership development as finding a cause; leadership development as learning from experience. This approach suggests that self-knowledge, self-concept clarity, and the internalization of the leader's role into the self-concept are achieved through the construction of life-stories (Shamir and Eilam, 2005).

Michie and Gooty (2005) base their conception of authentic leader and authentic leadership on emotion and positive psychology literatures to present an alternative approach to the role of emotions in leadership. Their approach suggests that frequent experiences of positive other-directed emotions motivate leaders to act on their other regarding values. They introduce an interactive approach to the cognitive and emotional processes that motivate authentic leaders to act in ways that are consistent with their self-transcendent values. They argue that consistency between a leader's self-transcendent values and actions is strengthened by the leader's capacity to experience positive otherdirected emotions. In the model presented by Michie and Gooty (2005), self-transcendent values comprise universal values (social justice, equality, and broadminded) and benevolent values (honesty, loyalty, and responsibility). They describe the selftranscendent behaviors of authentic leaders as: treat others fairly, treat others with respect, open to the ideas and opinions of others, transparent, and forego self-interest for the common good. Positive other-directed emotions include gratitude, appreciation, goodwill, and concern for others.

From the perspectives presented above, it is clear that authentic leadership development is entirely dependent on self-discretion of individuals. If someone realizes this fact, rest of the journey to development of authentic leadership style is not difficult, though 
it is not that easy too. It needs commitment, perseverance, consistency, and passion. It demands to convince only one person that lives inside the individual to pursue the authentic leadership development program. It is not time specific as well. Individuals can learn to be authentic from day-to-day life and apply their knowledge in their daily matters.

\section{CONCLUDING REMARKS}

Importance of leadership in project management is unquestionable. Several studies advocate the leadership and project leader as a critical success factors for projects. However, literature in project managements seems to have given less than deserved attention to project leadership. In this paper, the authors attempt to highlight the need for fresh understanding of project leadership by analyzing the leadership theories and styles mentioned in the literature. It is argued that current taxonomies of leadership styles are not sufficient to develop leaders who can meet the challenges of modern business world. Fast changing economies and businesses demand better and stronger project leaders who are confident, futuristic, flexible, moral, and competent. Leadership literature refers to such leaders as authentic leaders. They do not have to shift from one leadership style to another due to varying situations. They are consistent in their behaviors and lead with a conviction to achieve the project goals. In doing so, they do not compromise on principles, professional and social responsibilities, well-being of followers, and organizational values. The authors argue that such leaders are effective under all circumstances and have the potential to lead under complex conditions. The paper clarifies that these leaders are not perfect human beings; rather, they are true to themselves and illustrate behaviors and actions which are consistent with their character. They lead with both heart and mind. The paper posits that project leaders with authentic leadership style perform better and have greater likelihood of success. In the last section, the paper argues that authentic leadership development is a lifespan program and requires personal dedication and commitment to this very mission.

\section{REFERENCES}

Arain, F.M. (2005). Potential barriers in management of refurbishment projects, Journal of Independent Studies and Research, Vol. 3, No. 1, pp. 22-31.

Arain, F.M., Assaf, S., and Low, S.P. (2004). Causes of discrepancies between design and construction, Architectural Science Review, Vol. 47, No. 3, pp. 237-249.

Arain, F.M., and Low, S.P. (2005). Lesson learned from past projects for effective management of variation orders for institutional building projects, Proceedings of the MICRA 4th Annual Conference, Kuala Lumpur, Malaysia, pp. 10-1 to 10-18, ISBN: 9831002539.

Avolio, B.J., and Luthans, F. (2006). The High Impact Leader. New York: McGraw-Hill. 
Avolio, B.J., and Gardner, W.L. (2005). Authentic leadership development: Getting to the root of positive forms of leadership. The Leadership Quarterly, Vol. 16, No. 3, pp. 315-338.

Avolio, B.J., Luthans, F., and Walumbwa, F.O. (2004). Authentic leadership: Theorybuilding for veritable sustained performance. Working paper. Gallup Leadership Institute, University of Nebraska, Lincoln.

Bass, B.M., and Avolio, B. (1990). Transformational leadership development: Manual for the Multifactor Leadership Questionnaire. Palo Alto, CA: Consulting Psychologist Press.

Bass, B. (1996). A New Paradigm of Leadership: An Inquiry into Transformational Leadership, Army Research Institute for the Behavioral and Social Sciences, Alexandria, VA,

Bass B.M. (1985). Leadership and performance beyond expectations. New York: Free Press.

Bogus, S.M., and Rounds, J.L. (2006). Incorporating Leadership Skill Development in Construction Training Programs. Proceedings of the 2nd Specialty Conference on Leadership and Management in Construction, Grand Bahama Island, Bahamas, pp. $135-140$.

Bolman, L.G., and Deal, T.E. (1997). Reframing Organizations: Artistry, choice and leadership (2nd edition) San Francisco: Jossey-Bass.

Bonasso, S.G. (2001). Engineering, Leadership, and Integral Philosophy. Journal of Professional Issues in Engineering Education and Practice, Vol. 127, No. 1, pp. 17-25.

Bowman, B.A., and Farr, J.V. (2000). Embedding leadership in civil engineering education. Journal of Professional Issues in Engineering, Education, and Practice, Vol. 126, No. 1, pp. 16-20.

Bresnen, M., Bryman, A., Beardsworth, A., Ford, J., and Keil, E. (1986). Leader orientation of construction site managers. Journal of Construction Engineering and Management, ASCE, Vol. 112, No. 3, pp. 370-386.

Briner, W., Hastings, C., and Geddes, M. (1996). Project Leadership. Gower, Aldershot, England.

Bryman, A. (1993). Charismatic Leadership in Business Organizations: Some Neglected Issues, The Leadership Quarterly. Vol. 4, No. 3/4, pp. 289-304. 
Carr, P.G., Garza, M., and Vorster, M.C. (2002). Relationship Between Personality Traits and Performance for Engineering and Architectural Professionals Providing Design Services, Journal of Management in Engineering, Vol. 18, No. 4, pp. 158-166.

Chan, A.T., and Chan, E.H. (2005). Impact of Perceived Leadership Styles on Work Outcomes: Case of Building Professionals, Journal of Construction Engineering and Management, Vol. 131, No. 4, pp. 413-422.

Chanlat, J.F. (1996). From cultural imperialism to independence: Francophone resistance to Anglo-American definitions of management knowledge in Quebec, In Clegg S.R. and Palmer G. (eds.) The Politics of Management Knowledge, Sage, London, pp. $121-40$

Cheung, S.O., Ng, S.T., Lam, K.C., and Yue, W.M. (2001). A satisfying leadership behavior model for design consultants, International Journal of Project Management, Vol. 19, No. 7, pp. 421-429.

Cleland, D.I. (1995). Leadership and the project management body of knowledge, International Journal of Project Management, Vol. 13 No. 2, pp. 82-88.

Conger J.A., Kanungo R.N. (1987). Toward a behavioral theory of charismatic leadership in organizational settings, Academy of Management Review, Vol. 12, No. 4, pp. 637-647.

Conger, J.A. (1989). The Charismatic Leader: Behind the Mystique of Exceptional Leadership, San Francisco: Jossey-Bass.

Conger, J.A. (2004). Developing leadership capability: What's inside the black box? Academy of Management Executive, Vol. 18, No. 3, pp. 136-139.

Cooper, C.D., Scandura, T.A., and Schriesheim, C.A. (2005). Looking forward but learning from our past: Potential challenges to developing authentic leadership theory and authentic leaders, The Leadership Quarterly, Vol. 16, No. 3, pp. 475-493.

Cooke-Davies, T. (1990). Return of the Project Managers, Management Today, BIM, UK.

Daft, R.L. (2003). Management, Sixth Edition, Thomson, South Western, USA.

Dainty, A., Moore, D., and Murray, M. (2006). Communication in construction: Theory and practice, Taylor \& Francis, Oxon.

Dorfman, P.W., Howell, J.P., Hibino, S., Lee, J.K., Tate, U., and Bautista, A. (1997). Leadership in Western and Asian Countries: Commonalities and Differences in Effective Leadership Processes across Cultures, The Leadership Quarterly, Vol. 8, No. 3, pp. 233-274. 
Dulaimi, M., and Langford, D.A. (1999). Job Behaviour of Construction Project Managers: Determinants and Assessment, Journal of Construction Engineering and Management, Vol. 125, No. 4, pp. 256-264.

Dulaimi, M.F. (2005). The Influence of Academic Education And Formal Training On The Project Manager's Behavior, Journal of Construction Research, Vol. 6, No. 1, pp. 179-193.

Dulewicz and M.J. Higgs (2005). Assessing leadership dimensions, styles and organizational context, Journal of Managerial Psychology, Vol. 20, No. 2, pp. 105-123.

Enshassi, A., and Burgess, R. (1991). Managerial effectiveness and the style of management in the Middle East: An empirical analysis, Construction Management and Economics, Vol. 9, No. 1, pp. 79-92.

Fellows, R., Liu, A., and Fong, C.M. (2003). Leadership style and power relations in quantity surveying in Hong Kong, Construction Management and Economics, Vol. 21, No. 8, pp. 809-818.

Fiedler, F.E. (1967). A Theory of Leadership Effectiveness, McGraw-Hill, New York.

Gardner, W.L., Avolio, B.J., and Walumbwa, F. (2005). Authentic Leadership Theory and Practice: Origins, Effects and Development, Elsevier.

Gardner, W.L., Avolio, B.J., Luthans, F., May, D.R., and Walumbwa, F. (2005). "Can you see the real me?" A self-based model of authentic leader and follower development, The Leadership Quarterly. Vol. 16, No. 3, pp. 343-372.

Gil, F., Rico, R., Alcover, C.M., and Barrasa, A. (2005). Change-oriented leadership, satisfaction and performance in work groups: Effects of team climate and group potency, Journal of Managerial Psychology, Vol. 20, No. 3/4, pp. 312-328.

Gilbert, P. (1983). Styles of Project Management, Project Management Journal, Vol. 1, No. 4, pp. 189-193.

Giritli,H., and Oraz,T. (2004), Leadership Styles: Some evidence from the Turkish Construction Industry, Construction Management and Economics, Vol. 22, No. 3, pp. 253-262

Gharehbaghi, K., and McManus, K. (2003). The Construction Manger as a Leader, Leadership and Management in Engineering, Vol. 3, No. 1, pp. 56-58.

Goffee, R., and Jones, G. (2000). Why should anyone be led by you? Harvard Business Review.

George, B. (2003). Authentic Leadership: Rediscovering the Secrets to Creating Lasting Value, San Francisco: Jossey-Bass. 
Hersey, P., and Blanchard, K. (1982). Management of organizational behaviour (4th edn), Englewood Cliffs, NJ: Prentice-Hall.

Harrison, F. (1992). Advanced Project Management, Gower: Aldershot.

Harter, S. (2002). Authenticity. In Snyder, C.R., and Lopez, S.J. (Eds.), Handbook of positive psychology, pp. 382-394, Oxford, UK: Oxford University Press.

Hater, J.J., and Bass, B.M. (1988). Superiors evaluations and subordinates perceptions of transformational and transactional leadership, Journal of Applied Psychology, Vol. 73, No. 4, pp. 695-702.

House, R.J.(1971). A path-goal theory of leader effectiveness, Administrative Science Quarterly. Vol. 16, pp. 321-338.

Hopper, J.R. (1990). Human factors of project organization, A Report to the University of Texas, Construction Industry Institute, Austin, TX.

Ilies, R., Morgeson, F.P., and Nahrgang, J.D. (2005). Authentic leadership and eudaemonic well-being: Understanding leader-follower outcomes, The Leadership Quarterly, Vol. 16, No. 3, pp. 373-394.

Katzenbach, S. (1994). The Wisdom of Teams-Creating the High-Performance Organization, HarperCollins Publishers, Inc. NY.

Kangis, P., and Lee-Kelley, L. (2000). Project leadership in clinical research organizations, International Journal of Project Management, Vol. 18, No. 6, pp. 393-401.

Keegan, A.E., and Den Hartog, D.N. (2004). Transformational leadership in a project based environment: a comparative study, International Journal of Project Management, Vol. 22, No. 8, pp. 609-617.

Kotter, J.P. (1990). A Force for Change, New York: Free Press.

Lee-Kelley, L., and Loong, K.L. (2003). The Critical Elements of Managing IT Projects: An Investigation, International Journal of Project Management. Vol. 21, No. 8, pp, 583-591.

Lim, G.S., and Daft, R.L. (2004). The leadership experience in Asia, Singapore: Thomson Learning.

Long D.N., Ogunlana, S.O., and Lan, D.T. (2004). A Study on Project Success Factors on Large Construction Projects in Vietnam. Engineering, Construction and Architectural Management, Vol. 11, No. 6, pp. 404-413. 
Luthans, F., and Avolio, B.J. (2003). Authentic leadership development. In K.S. Cameron and J. E.Dutton and R. E. Quinn (Eds.), Positive organizational scholarship: Foundations of a new discipline: 241-258, San Francisco, CA: Berrett-Koehler.

Makilouko, M. (2004). Coping With Multicultural Projects: The Leadership Styles of Finish Project Managers, International Journal of Project Management, Vol. 22, No. 5, pp. 223-233.

McCuen, R.H. (1999). A course on engineering leadership, Journal of Professional Issues in Engineering Education and Practice. ASCE, Vol. 125, No. 3, pp. 79-82.

Michie, S., and Gooty, J. (2005). Values, emotions, and authenticity: Will the real leader please stand up? The Leadership Quarterly, Vol. 16, No. 3, pp. 441-457.

Monaghan T.J. (1981). An investigation of leadership styles and organizational structure, and their influence on the conduct of construction projects, unpublished M.Sc. thesis, Heriot-Watt University.

Mowson, T.C. (2001). Can we really train leadership? Leadership and Management in Engineering, Vol. 1, No. 3, pp. 44-45.

Muir, I., and Langford, D.A. (1994). Managerial Behaviour in Two Small Construction Organisations, International Journal of Project Management, Vol. 12, No. 4, pp. 244-253.

Naum, S. (2001). People \& Organizational Management in Construction, Thomas Telford, London.

Odusami, K.T. (2002). Perceptions of construction professionals concerning important skills of effective project leaders, Journal of Management in Engineering, Vol. 18, No. 2, pp. 61-67.

Odusami, K.T., Iyagba, R.R.O., and Omirin, M.M. (2003). The relationship between project leadership, team composition and construction project performance in Nigeria, International Journal of Project Management, Vol. 21 No. 7, pp. 519-527.

Ogunlana, S.O., Siddiqui, Z., Yisa, S., and Olomolaiye, P. (2002). Factors and procedures used in matching project managers to construction projects in Bangkok, International Journal of Project Management, Vol. 20, No. 5, pp. 385-400.

Odusami, K.T., and Ameh, O.J. (2006). The Leadership Profile Of Nigerian Construction Project Leaders, Proceedings of the 2nd Specialty Conference on Leadership and Management in Construction, Grand Bahama Island, Bahamas, pp. 135-140.

Powl, A., and Skitmore, R.M. (2005). Factors Hindering The Performance of Construction Project Managers, Construction Innovation, Vol. 5, No. 1, pp. 41-51. 
Rowlinson, S., Ho, T., and Yun, P. K. (1993). Leadership styles of construction managers in Hong Kong, Construction Management and Economics, Vol. 11, No. 6, pp. 455-465.

Ryff, C.D., and Keyes, C.L.M. (1995). The structure of psychological well-being revisited, Journal of Personal and Social Psychology, Vol. 69, No. 4, pp. 719-727.

Shamir, B., and Eilam, G. (2005). "What's your story?” A life-stories approach to authentic leadership development, The Leadership Quarterly, Vol. 16, No. 3, pp. 395-417.

Skipper, C., and Bell, L. (2006). Incorporating Leadership Skill Development in Construction Training Programs, Proceedings of the 2nd Specialty Conference on Leadership and Management in Construction, Grand Bahama Island, Bahamas, pp. 135-140.

Sutcliffe, N. (1999). Leadership behavior and business process reengineering (BPR) outcomes: an empirical analysis of $30 \mathrm{BPR}$ projects, Information \& Management, Vol. 36, No. 5, pp. 273-286.

Terry, R. (1993). Authentic leadership: Courage in action, San Francisco: Jossey-Bass.

Thite, M.R. (2000). Leadership styles in information technology projects, The International Journal of Project Management, Vol. 18, No. 4, pp. 235-241.

Thamhain, H.J. (2003). Team Leadership Effectiveness in Technology Based Project Environments, Project Management Journal, Vol. 35, No. 4, pp. 35-46.

Toor, S.R., and Ogunlana, S.O. (2005). What is Crucial for Success: Investigating the critical success factors and key performance indicators on mega construction projects, Proceedings of the Project Management Institute Singapore Chapter (SPMI) Annual Symposium, Singapore, pp. 1-10.

Toor, S.R., and Ogunlana, S.O. (2006). Successful Project Leadership: Understanding The Personality Traits of Project Managers and Organizational Factors, Proceedings of the CIB W107, Construction in Developing Economies International Symposium. Santiago, Chile.

Toor, S.R., and Ofori, G. (2006a). An Antecedental Model of Leadership Development, The Joint International Symposium of CIB Working Commissions W55/W65/W86, October, Rome, Italy.

Toor, S.R., and Ofori, G. (2006b). Leadership Flashback: An Antecedental Approach to Authentic Leadership Development, The Second Biennial Gallup Leadership Institute Summit, October, Washington D.C., USA.

Toor, S.R., and Ofori, G.O. (2006c). In Quest of Leadership in Construction Industry: New Arenas, New Challenges! The Joint International Conference on Construction Culture, Innovation, and Management (CCIM), November, Dubai, UAE. 
Toor, S.R., and Ofori, G. (2006d). Leadership Motives: Moving one step further, The Asia Pacific Structural Engineering and Construction (EASEC-10), Bangkok, Thailand.

Turner, J., and Muller, R. (2005). The project manager's leadership style as a success factor on projects: a literature review, Project Management Journal, Vol. 36, No. 2, pp. 49-61.

Vroom, V.H., and Jago, A.G. (1988). The New Leadership: Managing Participation in Organizations, Prentice-Hall, Englewood Cliffs, N.J.

Wang, E., Chou, H.W., and Jiang, J. (2005). The impacts of charismatic leadership style on team cohesiveness and overall performance during ERP implementation, International Journal of Project Management, Vol. 23, No. 3, pp. 173-180.

Wart, V.M. (2005). Dynamics of leadership in public service: theory and practice, ME Sharpe, Inc.

Yukl, G. (1999). An Evaluation of Conceptual Weaknesses in Transformational and Charismatic Leadership Theories, The Leadership Quarterly, Vol. 10, No. 2, pp. 285306.

Yukl, G. (2002). Leadership in Organizations, Prentice-Hall, Saddle River, N.J.

Yang, O., and Shao, Y.E. (1996). Shared leadership in self-managed teams: A competing values approach, Total Quality Management, Vol. 75, No. 5, pp. 521-535.

By "strategic management", we refer to the formulation of company missions, purposes, and objectives; the policies and programs to achieve them; and the methods needed to assure that they are implemented. In the past, strategic management meant essentially adapting to the economic and technical environments. Now it means adapting also to the sociopolitical environment. Indeed, sociopolitical environmental forces are as dominant influences on corporate strategy as traditional market forces.

The concept of strategic management does not imply that managements formulate strategies only in response to current events. Quite the contrary, it means that managers try to anticipate future environmental forces so that they can take proactive measures to deal with them. Stenier and Steiner: Business, Government and Society: A Managerial Perspective 